\title{
A Corporate Governance Agenda for Developing Countries
}

\author{
Tatiana Nenova*
}

\section{Section I. Concentrated Ownership. Separation of Ownership and Control}

\subsection{Introduction}

Uuccessful entrepreneurs face the need to raise financing as their business grows, $\checkmark$ initially from debt and thereafter from equity markets. As entrepreneurs share ownership with investors, they tend to retain a disproportionate amount of control over the venture. This divergence creates incentives for value transfers from noncontrolling investors to the dominant corporate owner. Examples here can range from the proverbial personal usage of the corporate jet, and the installation of possibly unqualified family members in managerial positions, to abortive empirebuilding ambitions of the controlling party at the expense of minority investors, or outright self-dealing transactions. Corporate governance deals with the impact of the separation between ownership and control, as well as with solutions for the resulting agency problems.

How is self-dealing, and other value transfers away from the minority, achieved in practice? The most common technique is the related-party transaction (RPTs), or a transaction between the controlled company and the controlling party. Examples are sales to the company at inflated prices or purchases from it at excessively low prices, loans to/from the company at advantageous terms, or even an outright transfer of company assets to the controlling party. In most developing countries, those deals can be fully legal. Aside from RPTs, popular expropriation strategies include: to fail to pay sufficient dividends; to dilute the minority stake by issuing additional shares in the absence of pre-emptive rights; to fail to share merger and

\footnotetext{
* Financial Economist, Policy Practice, Corporate Governance Department, The World Bank Group. E-mail: tnenova@worldbank.org
} 
acquisition gains with the minority; to buy out the minority at deflated prices and take the firm private (a minority freeze-out). Yet another mechanism for value theft, popular in liquid and developed markets, is insider trading.

How rampant are such value transfers around the world? In Russia, privatized assets sold at a $99 \%$ discount relative to Western counterparts, to an important extent due to managerial ability to divert funds, as well as to political and regulatory risk. ${ }^{1}$ In the Czech Republic, the controlling block of shares sells at $58 \%$ premium, reflecting the importance of possessing control in the corporation, as well as the inability for small investors to fully protect the value of their invested funds. Control value in Brazil increases more than twice, to 25\%, in the second half of 1997 in response to the legislation which scrapped significant minority protection mechanisms. ${ }^{2}$ In Korea and Mexico, control is worth $48 \%$ and $36 \%$ of the value of the entire company. The benefits of control for the controlling manager, at the expense of smaller investors, can reach $82 \%$ in Italy, and $20 \%$ in Switzerland. In contrast, self-dealing in Japan, Germany, UK and US, to name but a few countries, is on a significantly smaller scale. ${ }^{3}$ Laws and their enforcement explain the bulk of such differences across countries in a sample of OECD and mid-income countries. ${ }^{4}$

Indian firms who receive unexpectedly higher earnings, have been found to transmit the entire cash up the pyramid, without sharing with any members of the business group. Moreover, the cash follows ownership lines, in case of several large shareholders. Much of this value diversion is found to occur on non-operating components of profits. ${ }^{5}$ In Canada, "ultimate owners, mostly families, tend to make pervasive use of opportunistic practices aimed at stripping assets from subsidiaries and re-deploying cash flows from "affiliated cash cows" in favor of tightly held firms in a fashion fitting their personal utility." In their work on tunneling, Johnson et al find an increased incidence of looting of firms by their controlling shareholders during the emerging markets crisis of 1997-1998: "Assets were transferred out of

${ }^{1}$ Boycko, Shleifer Vishny 1993.

2 Nenova, 2000.

${ }^{3}$ Zingales 1994, Horner 1988, Megginson 1990, Zingales 1995, Dyck and Zingales 2002.

${ }^{4}$ Nenova, 2003.

${ }^{5}$ Bertrand, Mehta, and Mullainathan, "Ferreting out Tunneling: An Application to Indian Business Groups", 2000 .

${ }^{6}$ Atting, Fischer, Gadhoum, "On the Determinants of Pyramidal Ownership: Evidence on Dilution of Minority Interests”, 2003. 
companies, profits siphoned off to escape creditors, and troubled firms in a group propped up using loan guarantees by other listed group members." 7

\subsection{Concentrated ownership around the world}

Given that minority expropriation is stimulated by the presence of dominant owners, as well as the diversion between share ownership and control, how prevalent are those phenomena in practice? The literature finds that concentrated ownership is the rule for the largest listed companies in countries at various stages of development and from all regions of the world. ${ }^{8}$ For developing countries, the average firm is majority controlled. Ownership concentration is even higher for smaller firms, as the following examples from East Asia illustrate. "This pattern is especially strong in Japan, where only one of the largest 20 firms is in family control, while $57 \%$ of the smallest 50 companies are controlled by families. The same dramatic increase in family control is observed in Korea, where only four of the largest 20 companies are family controlled, while 48 of the smallest 50 companies fall into that category. The magnitude of the increase of family control in smaller companies is similar in Taiwan, from $15 \%$ to $80 \%$ of the sample [...] The evidence also suggests that in some countries a significant share of corporate assets rests in the hands of a small number of families. At the extreme, $16.6 \%$ and $17.1 \%$ of the total value of listed corporate assets in Indonesia and the Philippines, respectively, can be traced to the ultimate control of a single family. The largest ten families in Indonesia, the Philippines, and Thailand control half of the corporate assets in our sample, while the largest ten families in Hong Kong and Korea control about a third of the corporate sector." 9

Large family owners are the norm not only in East Asia, but around the world. Out of 225 listed firms in Brazil, 90\% are majority controlled, on average with $76 \%$ of the voting capital, but only $54 \%$ of the total capital. Of the majority controlled firms, $53 \%$ are controlled by families, $30 \%$ by foreign investors, $9 \%$ by institutional investors and $8 \%$ by the government. Pyramidal structures and shareholding agreements are frequent, especially among family firms. ${ }^{10}$ In Colombia, the stock exchange free float averages $15 \%$ and has been decreasing as controlling

\footnotetext{
7 Johnson, La Porta, Lopez-de-silanes, and Shleifer, "Tunnelling", 2000.

${ }^{8}$ La Porta, Lopez-de-silanes, and Shleifer, "Ownership around the World", 1999.

${ }^{9}$ Claessens, Djankov, Lang 2000

${ }^{10}$ Carvalhal Da Silva and Leal, "Corporate Governance. Market Valuation and Dividend Policy in Brazil".
} 
shareholders increase their stakes. ${ }^{11}$ Four large business groups dominate Colombia's corporate sector, three include listed firms. ${ }^{12}$ In 2002, nine of the ten largest firms by trading volume belonged to one of the groups.

Turkish business groups are organized around a holding company ultimately owned by a family, and include a private bank that serves as the main bank of the group. The typical Turkish holding company uses a complicated web of inter-corporate shareholdings and pyramidal structures, which permit easy fund diversion away from publicly owned corporations to privately owned ones. CMBT weekly bulletins are replete with revision requests related to internal transfers. ${ }^{13}$ The most common ultimate owners are families, controlling $72 \%$ of the 100 largest listed firms in Turkey, with an average of $52 \%$ of the votes, and $24 \%$ of the capital. ${ }^{14}$ Slovenian firms have somewhat less concentrated ownership than the rest of Europe - the largest voting block is below $35 \%$, while half of the companies in the capital market do not have an owner holding more than $25 \%$. On the other hand, about $20-25 \%$ of the shares are dispersed among employees that often represent hidden support of Slovenian managers. There are usually 3 to 7 large blockholders in addition to the main owner. Ownership has been steadily consolidating, however, as the average increase of the largest voting block in 1999-2002 was 10.32 percentage points. ${ }^{15}$ More than $70 \%$ of Polish listed companies are majority controlled, and more than $85 \%$ are controlled at least at the $25 \%$ level.

In South Africa, in contrast, ownership concentration has decreased drastically since the early 1990s. The South African economy was historically dominated by six mining finance houses. As late as 1989 the Anglo American/De Beers grouping controlled 10 of the 20 largest JSE companies by market capitalization. Integral to the system were related-party transactions in the form of guaranteed management contracts for the houses. Shareholder pressure has led to the dismantling of these control structures. Houses have 'unbundled' their stakes in non-core holdings to their shareholders and, in the case of core holdings, bought out minority shareholders.

\footnotetext{
11 Source: Bolsa de Valores de Colombia, May 2003. Resolution 275 (2001) establishes a minimum free float of 20 percent in four years for companies who want to attract pension fund investment.

12 The Santo Domingo Group (e.g. Bavaria, Caracol), Ardilla Lulle (e.g. RCM, Coca Cola/Pepsi Cola, Textiles), Grupo Aval (e.g. Banco Bogotá), Sindicato Antioqueño (e.g. Cementos Algos)

${ }^{13}$ Corporate Governance Assessment: The Turkish Equity Market, Zühtü AYTAÇ and Güven SAK, 2000.

14 Demirag and Serter, “Ownership Patterns and Control in Turkish Listed Companies", 2003.

15 Gregoric and Vespro 2003, "Block Trades an the Benefits of Control on Slovenia".
} 
These steps eliminate the conflict of interest between minority investors and the controlling house, and the practice of management contracts has virtually ceased. ${ }^{16}$ Market pressure has led to the dismantling of many pyramids, and listing of new ones is prohibited. ${ }^{17}$ In 1989, 53 JSE listed firms, or $12 \%$ of the market by value, were controlled by pyramids; by the end of 2000, 16 companies, or $6 \%$ of the market by value had pyramid control. $\mathrm{N}$-shares ${ }^{18}$ have followed the same trajectory as pyramids: popularity in the early 1990s, followed by market disillusionment and outright prohibition of new N-share listings in 2000. Many N-shares have been converted to ordinary shares under market pressure, and the number of $\mathrm{N}$-shares traded on the JSE fell from 26 to 14 between 1996 and 2000. The aggregate value of companies with $\mathrm{N}$-shares now comprises less than $1 \%$ of the market capitalization of the JSE.

\subsection{Incidence of separating ownership and control around the world}

Not only is ownership concentrated around the world, but there are many more opportunities to separate ownership from control. Some mechanism to achieve this were illustrated above: multiple share classes with different voting rights, pyramids, cross-shareholdings, and shareholder agreements. Other tools, such as golden shares and voting caps, are also discussed below.

The most common deviation from one-share-one-vote is via non-voting shares or multiple-voting shares, pyramids, and cross-shareholdings. Several share classes are used to concentrate control in a small amount of capital. This, majority control can be achieved in Brazil with 16.7\% of the capital, using PN shares. ${ }^{19}$ The average percentage of cash-flow rights required to control a company with $\mathrm{N}$-shares in South Africa is $17.1 \%$. Non-voting shares can be limited as a percentage of total capital, to avoid extreme separation of ownership and control: in the Slovak and Czech Republics, to 50\% of total capital, and in Morocco - to 25\%. Most countries have no limit. Non-voting shares are forbidden in some countries, such as Poland. Such shares usually, but not always, carry preferential dividend rights. Preferred shares in Latvia obtain voting rights after 3 years of dividend non-payment. Non-

\footnotetext{
${ }^{16}$ Malherbe and Segal (2001).

17 JSE Listing Requirements, 2000.

18 South African N-shares usually have $1 / 100$ of the voting power of equivalent ordinary shares.

19 This figure is $25 \%$ for companies listed since October 2001, as the limit of maximum PN shares a firm can issue was lowered from $67 \%$ to $50 \%$ of capital.
} 
voting shares in Brazil and Mexico can elect fiscal boards to police the Board of Directors and management. Multiple-voting shares concentrate voting power is a small amount of capital. To limit this effect, such shares may be capped at a certain maximum amount of voting power, such as 5 votes per share in Latvia and 3 in Poland. Multiple-voting shares are not allowed in Chile, Colombia, Czech Republic, Georgia, India, Malaysia, and Ukraine. In Egypt, interestingly, multiple-voting shares tend to have preference in dividend distributions. ${ }^{20}$ In India, the listing requirement of one-share-one-vote was scrapped in 2002.

Families are actively involved in corporate management as well, as the example of Hong Kong illustrates. Over $70 \%$ of listed companies are majority controlled by a family. The ten wealthiest families controlled $47 \%$ of the total market capitalization of the SEHK in 2000. Control is secured via pyramids, cross-shareholding or interlocking directorships, and a large separation of voting from cash flow rights. On average, the board of directors holds $44 \%$ of the capital, and they hold at least $1 / 3^{\text {rd }}$ in $85 \%$ of the firms. In general, Hong Kong-listed firms are owned and managed through blood and marriage ties. Many of these family members also actively participate in the daily operations of their firms by appointing themselves or trusted relatives and colleagues as senior executives or board directors. The average percentage of family members sitting on boards was $32 \% .{ }^{21}$ An example of a typical pyramid is Hutchison Whampoa, the third largest listed Hong Kong firm (Figure 1). Pyramids extend the controller's reach, while allowing for a limited monetary investment. It is $43.9 \%$ controlled by Cheung Kong Holdings, the fifth largest listed firm. In turn, the Li Ka Shing family owns 35\% of Cheung Kong. The family achieves complete control over both listed firms, while holding only half of the capital of the first pyramid level. Outside shareholders contribute to the remaining capital at both pyramid levels.

\footnotetext{
${ }^{20}$ Capaul and Fremond, "Capital Structures and Control Rights: Patterns, Trade-offs, and Policy Implications".

${ }^{21}$ Ho, 2003, "Corporate Governance in Hong Kong: Key Problems and Prospects".
} 
Figure 1

\section{Ownership strictre of Hutchison Whampoa(Hong Kong)}

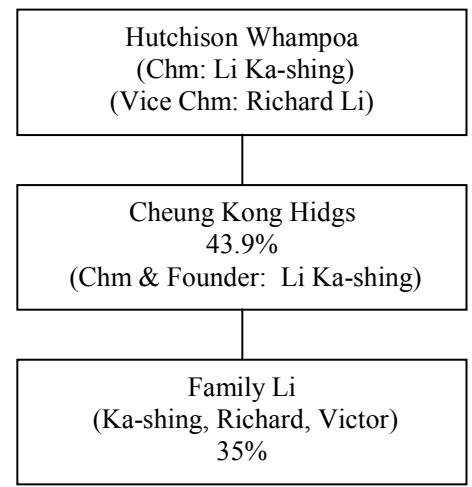

Source: La Porta, Lopez-de-silanes, Shleifer, 1999, "Ownership around the World”

The full use of pyramids, cross-shareholdings, and diverging cash flow and voting rights can be illustrated on the case of the largest conglomerate in the Philippines, Ayala Group (Figure 2). Ayala Corp, the second largest publicly owned company, is $58 \%$ controlled by the Ayala family through a wholly-owned family vehicle, Mermac Inc. Ayala Corp. owns $69 \%$ of the capital and $77 \%$ of the votes in Ayala Land, the largest listed firm, which in turn has 5\% of the cash-flow and control rights of Ayala Corp., an example of cross-holdings between companies in the same group. The separation between ownership and control of Ayala Corp. is due to the existence of some shares with superior voting rights. In another example of a crossholding, Ayala Corp. has $90 \%$ of the shares in the Ayala Foundation and $34 \%$ of the shares in the Bank of the Philippine Islands (the $5^{\text {th }}$ largest listed firm); the Ayala Foundation, in turn, has $9 \%$ of the shares in the BPI. Cross-shareholdings can create a maze where the identities of beneficial owners and controllers are difficult to distinguish, especially if used in conjunction with pyramids. Crossshareholdings are popular in East Asia, especially Hong Kong, and Korea. While pyramids are prevalent in Chile, cross-shareholdings are prohibited. 
Figure 2

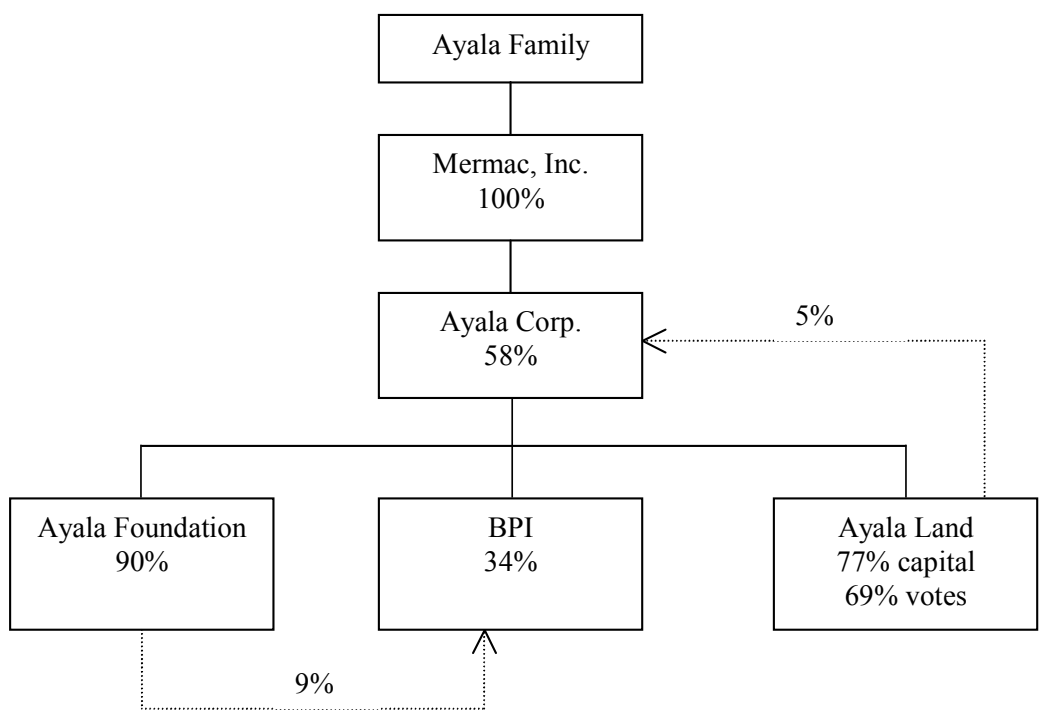

Deviations from one-share-one-vote are very common in Latin America, Africa, and the Middle East, and least common among OECD countries (though still present in more than half of the countries). In contrast, pyramids and crossshareholdings are popular in East and South Asia. Aside from the poorest countries, where such mechanisms are not needed for tunneling as cheaper alternatives are available, and the richest countries, where such deviations are strictly regulated, all three methods for concentrating control are very popular. In general, common law countries use the least amount of pyramids, deviations from one-share-onevote, and cross-shareholdings, and French civil law countries make the most use of them. 
Table 1

\begin{tabular}{|c|c|c|c|}
\hline & \multicolumn{3}{|c|}{ Percent of countries where: } \\
\hline Region & $\begin{array}{c}\text { 1-share-1-vote is } \\
\text { used: }\end{array}$ & $\begin{array}{c}\text { Pyramids } \\
\text { are rare: }\end{array}$ & $\begin{array}{c}\text { Cross-shareholdings } \\
\text { are rare: }\end{array}$ \\
\hline Africa & $0 \%$ & $60 \%$ & $60 \%$ \\
\hline EAP & $20 \%$ & $0 \%$ & $0 \%$ \\
\hline ECA & $30 \%$ & $75 \%$ & $63 \%$ \\
\hline LAC & $0 \%$ & $25 \%$ & $50 \%$ \\
\hline MENA & $50 \%$ & $50 \%$ & $100 \%$ \\
\hline OECD & $43 \%$ & $52 \%$ & $65 \%$ \\
\hline SA & $25 \%$ & $0 \%$ & $33 \%$ \\
\hline Income quartile & & & \\
\hline Low & $50 \%$ & $50 \%$ & $100 \%$ \\
\hline Mid-low & $11 \%$ & $29 \%$ & $29 \%$ \\
\hline Mid-high & $11 \%$ & $41 \%$ & $47 \%$ \\
\hline High & $43 \%$ & $50 \%$ & $64 \%$ \\
\hline Legal origin & & & \\
\hline English & $41 \%$ & $50 \%$ & $63 \%$ \\
\hline French & $19 \%$ & $24 \%$ & $48 \%$ \\
\hline Geman & $33 \%$ & $64 \%$ & $64 \%$ \\
\hline Scandinavian & $0 \%$ & $75 \%$ & $75 \%$ \\
\hline Transition & $33 \%$ & $50 \%$ & $0 \%$ \\
\hline
\end{tabular}

There are other, less widespread, mechanisms for concentrating control. First, the golden share can prescribe special powers to its owners. In Chile and Mexico, ("preferential shares") hold disproportionate power to elect directors. ${ }^{22}$ Local, regional, and state governments, hold golden shares in large or strategic companies, in Brazil, Malaysia, Turkey, Hungary, and Lithuania, for example. ${ }^{23}$ Second, voting caps can limit the votes a single shareholder can cast. For example, the Bettencourt family can dominate Nestle with a stake of barely $10 \%$, as the voting cap does not permit any shareholder to yield more than $3 \%$ of the voting power. Voting caps are forbidden in certain countries, such as Czech Republic, Hungary, Korea, Mexico, Poland, Slovakia, Turkey, Malaysia and the Philippines. Voting caps can be used as poison pills to prevent a change in control, so in Hungary provisions mandating voting caps become null and void during a public bid. ${ }^{24}$ Voting power can be acquired

\footnotetext{
${ }^{22}$ For example, the Chilean company SQM has class A and B shares with the same economic and voting rights at shareholder meetings, except that class A can elect 7 of the 8 directors.

${ }^{23}$ Capaul and Fremond.

${ }^{24}$ Capaul and Fremond; Claessens, Djankov, Lang.
} 
while saving on investment capital, by paying shares only in part. Most countries provide for receipt of voting power only upon full payment of acquired shares; however, Egypt and Singapore do allow that.

Shareholder agreements are not deviations from one-share-one-vote per se, but if not disclosed, can distort understanding of the true controlling party of the company. Such agreements involve a binding policy of acting in concert, including voting decisions. For example, in Bulgaria, the privatization funds were limited from acquiring stakes higher than $34 \%$ in the auctions, and an ownership pattern emerged where there is informal understanding between pairs of privatization funds who own $34 \%$ and $17 \%$ blocks in two respective companies, reciprocating assurances of majority control. Informal alliances can also be illustrated on the example of Thai companies. Only $40 \%$ of non-widely held Thai firms have a single ultimate owner, and use of pyramids and cross-holdings is low. This reflects the importance in Thailand of informal alliances among the small number of families controlling most Thai companies. Often, several families will jointly own a large stake in a corporation, with one family in the alliance taking the role of primary controlling shareholder; Suehiro (1993) describes interfamily business cooperation in Thailand. ${ }^{25}$ Shareholder agreements must be disclosed in Lithuania and Colombia, but not in India, Indonesia, Slovenia. Enforcement if disclosure is not trivial - in Lithuania, non-disclosed agreements had to be deprived of voting rights before proper disclosure was effectively enforced.

\section{Section II. Major Self-dealing Mechanisms. The Role of Disclosure}

The law's ability to limit the expropriation of investors critically depends on differences in the structure of ownership and control among firms in countries at various stages of development. In countries with developed capital markets and legal / regulatory frameworks, the cost of corporate value theft is high, in view of superior information, the threat of lawsuits, and the sophistication of the market players. In such countries, corporate value diversion, within the limits of the law, is relatively low in level. In exactly those circumstances, however, to limit such expropriatory actions, laws need increasing sophistication and a higher level of

${ }^{25}$ Claessens, Djankov, Lang 2000. 
enforcement. In countries with less developed markets, lower disclosure standards, and a weaker legal system, including limited enforcement capacity, value extraction is less costly, and it is mostly done off the market. Predictably, expropriation levels are higher, as numerous academic studies document. ${ }^{26}$ A more important observation to note, is that in such countries insiders (controlling shareholders and their boards of directors / auditors / managers) are sole at the helm of the company, with full decision-making power, mostly unaccountable to either dispersed shareholders or the regulatory authorities. Inadequate disclosure of their actions, as well as poor enforcement powers of regulators contribute to this fact.

On the other hand, dispersed ownership is not the answer. Large shareholders are an optimal response to weak enforcement and have a role to supplant weak laws. "Wholesale transfer of governance standards from developed market economies may, for example, discourage investors from taking controlling positions. Moreover, standards that are not transplanted without sufficient domestic debate and adaptation are less likely to be adhered to or enforced. In the near term, corporate governance mechanisms in developing and transition countries have to function and reform has to be implemented in an environment where courts and other enforcing institutions are weak. The challenge is thus not to undermine concentrated ownership - which is perhaps the most potent corporate governance mechanism in less developed economies. Instead, it is to mitigate the social and economic costs which can come along with these ownership structures." ${ }^{27}$

The 2002 revisions to the Securities Law in Romania elicited clearly the boundary between adequate and excessive minority rights protection, as controllers threatened to de-list their firms. Currently, certain investors in Chile abuse minority powers by buying blocks in firms and engaging in value extortion. Firms are responding by decreasing the number of Board members so larger blocks are needed to elect a single member. In Lithuania, minority shareholders abuse withdrawal rights to get bought out at a higher price. In the Philippines, where the court has been predictable and systematic in enforcing disclosure by insiders, the minorities have already taken to abusing the court requests for corporate information. Finally, in Slovakia, a 5\% threshold for calling an AGM and initiating other shareholder redress was recently introduced. As a result, well-connected small shareholders have attempted to acquire

${ }^{26}$ See the "law and finance" literature, summarized recently in LLSV (1999).
${ }_{27}$ Berglof and Claessens, "Enforcement and Corporate Governance", 2003. 
small stakes in order to hold the company "for ransom" (greenmail), and several large companies appear to be delisting rather than fact this risk. ${ }^{28}$

\subsection{Most widely used expropriation techniques: RPTs for poorly developed markets}

Related party transactions (RPTs) have the potential for significant value diversion away from the listed firms and into the hands of the controlling shareholder. As a first line of enforcement defense, such deals are required to be disclosed in the Annual Report, usually in the notes of the financial statements. To assure high standard of disclosure, an auditor is required to certify the veracity of such transactions as described in the Annual Report. For example, in the Philippines, such disclosure and auditing is required for all deals involving the company and any of its subsidiaries in which a director, executive officer or stockholder owns at least $10 \%$ of the total outstanding shares, and the members of their immediate family had a material interest. In spite of such provisions, there is still concern among market participants that the provision is not consistently adhered to in an environment of pyramid structures and majority shareholder control, with family dominance.

A second potential line of abuse concerns the strictness of the definition of an RPT. In India, adequate disclosure is enforced; but it proves insufficient to protect minority shareholders from potential abuse. This is because some firms obey the letter, not the spirit, of the law. One example is to restrict ownership in a company to 49.9 percent to avoid having to call it a "subsidiary." Thus, misuse of corporate assets and abuse in related party transactions remain problems. In Peru, there is significant scope for interpretation as to which RPTs should be disclosed. As a result, disclosure in practice is limited to deals with subsidiaries and associate companies of the same business group, and does not include directors, management and major shareholders. CONASEV does not appear to have the necessary infrastructure to engage in meaningful oversight, as attested by two recent well publicizeted by two recent well publicizehe expropriation of owners of investment

\footnotetext{
${ }^{28}$ Fremond / Capaul
} 
shares. ${ }^{29}$ The same issue poses itself in Indonesia, where the definition of RPTs is confusing. Bapepam leads firms to rely on a lawyer's opinion in deciding the need for disclosure, increasing the cost and arbitrariness of compliance with RPOT rules for good faith firms, and allowing much potential for abuse by entities acting in bad faith.

A third line of defense is an AGM approval of such deals. In Chile, large firms must form a comité ejecutivo de directores, which pre-vets RPTs and indicates whether they meet market conditions. The board must either approve or reject the transaction with the abstention of the interested director or, if the board is unable to reach a decision, hire two independent evaluators. Their reports are available to the board and shareholders for 20 working days and transmitted to the regulator. RPTs must be disclosed at AGMs. Practice suggests that despite all efforts, misuse of corporate assets and abuse in connected party transactions remain a recurrent problem in Chile. Thus is due to problems in identifying "related parties" given the complicated ownership and control structure of most conglomerates. In Colombia, RPTs require AGM authorization, ${ }^{30}$ but according to market observers, this rule is rarely observed. Due to concentrated ownership, RPTs do not take place under desired levels of transparency and are not sufficiently regulated. ${ }^{31}$ This is one of the most problematic issues in the Colombian securities market.

In sum, disclosure, board responsibility, clear rules, and AGM approvals are necessary, but not sufficient conditions for self-dealing prevention. RPT cases underscore the importance of true director independence in Argentina, and test the efficiency of the court system in South Africa, ${ }^{32}$ as well as surface (as was recently observed) in the US. However, though disclosure and enforcement may not be

\footnotetext{
${ }^{29}$ In one instance, the controlling shareholders approved the merger of their loss-making wholly owned subsidiary with the listed company which had the effect of wiping out the distributable earnings of the listed company. In another case, a mining company sold a valuable mining asset to a related company. When holders of investment shares complained about losing this potentially valuable stream of revenue, the controlling shareholders bought them out at a small premium.

${ }^{30}$ Article 23 of Law 222 of 1995

${ }^{31}$ Interview with Doctor Flórez, Deputy Superintendent for Listed Companies.

${ }^{32}$ Regal Treasury Private Bank (South Africa) was rockerd by revelations that it provided loans to a number of trusts to buy $45 \%$ of the shares of its parent company, Regal Treasury Bank Holdings. ("Another small bank trips", Business Day, 26/06/2001)
} 
capable of eliminating self-dealing, they can go a long way towards limiting such activity and preserving minority shareholder value.

\subsection{Most widely used expropriation techniques: Insider trading for mid- level developed markets}

Insider trading is a potentially powerful self-dealing technique in mid-level developed markets, where the liquidity and the number of listed firms permits profitable trading on insider information, with relatively frequent opportunities to do so, and with a somewhat slighter chance of scandal or legal complications. India, Philippines, Russia may be appropriate examples. On the other hand, the Panama stock exchange where some firms trade once a month, and there is a total of 25 listed firms in all, a profitable opportunity to trade on insider information is rare; and the chance of that trade being publicly visible is high. As the case of Indonesia illustrates, civil law proof standards are stringent enough to hamper court prosecution of insider trading in most countries (Box 5). In Colombia, there has been no sanction imposed by the Superintendency of Securities regarding misuse of "Información Privilegiada" in the past 5 years, again due to the difficulties posed by law for the investigation and prosecution of these cases, namely lack of sufficient powers to obtain evidence to incriminate the people involved in such situations. As another example, in the Philippines there has been no prosecution for insider trading in the last five years and only one case brought before the courts, BW Resources Corporation, a gaming and real estate company. The key shareholder of BW Resources, Mr. Dante Tan, and a number of stockbrokers were charged by the SEC before the Department of Justice, of stock price manipulation in 1999. The case is still unresolved. ${ }^{33}$ Second, fines are typically too low to defer malfeasance. Finally, there is typically a shortage of information exchange among the regulatory agencies (SEC, clearing house, exchange, others), for adequate insider trading prevention and enforcement. India is making its first steps into insider trading enforcement. SEBI has already initiated 5 cases. Anecdotal evidence suggests that front running remains a problem. An additional factor making surveillance more difficult, are multiple listings. To address these problems, SEBI is in the process of setting up a unique client code (UCC) for each investor. ${ }^{34}$ The case of Mr. Arora (Box 1) is illustrative.

${ }^{33}$ Source: Business World, editions 1999

${ }^{34}$ The UCC in effect now is not "unique" in the sense that the same person can have various UCCs 
A success case example of insider trading rules enforcement is Chile, where such infractions are much less of a problem currently as compared to several years ago. First, disclosure was drastically improved in the 1980s, making it difficult to conceal trades on private information. Second, insider dealing is a criminal offense in Chile. ${ }^{35}$ Over the last five years, SVS has pursued about 20 cases, five of which resulted in the prosecution of 12 people. However, most cases are still on trial, and SVS's administrative sanctions have been suspended pending resolution in the courts. SVS tools to detect insider dealings are planned to be further strengthened: it lacks an electronic surveillance system and cannot access investor phone records. ${ }^{36}$ The Stock Exchange participates in monitoring as well and may suspend transactions for up to five days if it suspects that relevant information is unknown to the market. ${ }^{37}$ South Africa insider trading enforcement also strengthened considerably after the adoption of a new Insider Trading Act in 1998, and the conduct of a couple of major high-profile cases with severe penalties (but no criminal liability).

35 Article 60 of the Securities Market Law. Prison terms can range from 180 days to five years.

${ }^{36}$ The Second Reform to the Capital Market proposes an amendment to allow SVS to access telephone records.

${ }^{37}$ Article 44, SML. 


\section{Box 1 \\ The Insider Dealing Investigation of Samir Arora}

The first time SEBI invoked the unfair trade practice clauses of the SEBI Act was on August 9, 2003, when SEBI banned Samir Arora, former chief investment officer of Alliance Mutual Fund, from dealing in securities for insider trading. Alliance Capital's directors/trustees were charged with rigging bids, trading on insider information, and failing to make proper disclosures. None if these charges are self-evident and unproblematic.

The first charge is due to Mr. Arora's switch-over of positions from Alliance to Henderson Global Investors, as Henderson was bidding to acquire Alliance. According to SEBI, the change of jobs of Mr. Arora caused a fall in the value of Alliance, making it cheaper for Henderson to acquire. The succes of tihs charge hinges upon proving the motive behind Arora's alleged deal with Henderson, a generally hard undertaking. The second charge accuses Mr. Arora of selling Digital Global Soft shares just before merger news that drastically reduced the share value. This insider trading charge is also difficult to prove, as SEBI must provide evidence of possession and communication of unpublished pricesensitive information, a non-trivial task. Finally, teh third charge is that Alliance failed to make adequate disclosures when it acquired more than $5 \%$ or when its shareholdings changed by more than $2 \%$ in firms such as Mastek. Digital GlobalSoft, Hinduja TMT, Balaji Telefilms and United Phosphorus. Such a charge does not carry severe penalties.

Source: India ROSC

\subsection{Enforcement of Corporate Governance and Minority Rights - The Role of Disclosure}

Under the concentrated ownership structures prevalent in developing countries, controlling shareholders are often also managers and dominate the board. The checks and balances arising from the division of power between board/management/ controlling shareholders do not apply in the same way as in countries with widely dispersed ownership or in countries with several important blockholders, such as Western Europe. As a result, corporate matters are an opaque, insider-controlled area, unapproachable by outside minority investors and impervious to their approach. Independent of the quality of the laws, their enforcement, and the zeal and commitment of the Securities Supervisor and the stock exchange, as well as outside 
shareholders themselves, any success in achieving good corporate governance is predicated upon disclosure and transparency. Disclosure is also relatively cheap, as compared to private court action, or the additional expense of arming the Securities Supervisor with enforcement of extensive securities rules. Finally, disclosure has the virtue of possessing a self-enforcement element, to the extent that it can have a "shaming effect" via the media, or reputational concerns, when enforcement by the court or the Securities Supervisor is weak. To protect shareholder rights, corporate governance frameworks must ensure the availability, quality and timeliness of financial and non financial information to allow shareholders to take rational decisions. Studies show that transparency effectively lowers the corporate cost of capital. ${ }^{38}$

One of the most important pieces of information is the identity of the ultimate owner. Yet in approximately half of the countries with stock markets, indirect and beneficial ownership is not publicly disclosed, by law. In Egypt, there is no ownership disclosure and generally poor transparency, due to a culture of secrecy as well as sheet technical difficulty in maintaining corporate information. 551 listed firms by law have almost no disclosure obligations as they are too small (filing of annual and quarterly reports is only mandated for listed firms with 100 employees or more). In July 2002 new listing rules went into effect that increased disclosure and corporate governance requirements for listed firms. CASE has renewed its commitment to enforce the listing rules, delisting 99 firms in the first month when the new rules entered into force (Sep. 2003), and . As a result, a net of 99 companies had been de-listed for failing to observe the new listing rules by end-September 2003, and planning to de-list 300 more issuers over the subsequent months. In Tunisia, ownership information is reported to the Securities Supervisor, but is not publicly available. Even if mandated by law, disclosure is not always enforced, as in Colombia and the Philippines. In Brazil, ownership is well documented, and is available realtime; however, as shareholders exercise their right to request an updated shareholder list, some companies reportedly attempt to discourage investors by charging exorbitant prices, and shareholder agreements are not always duly deposited with the company. In Lithuania, companies abuse the confidentiality procedure to limit disclosure. In Indonesia shareholders who would like to inspect the shareholders' register maintained by the Securities Administration Bureau would

${ }^{38}$ Chen, Chen and Wei, "Disclosure, Corporate Governance, and the Cost of Equity Capital: Evidence form Asia's Emerging Markets". 
be informed by BAI to obtain the prior approval of the company's board of directors. Mexico provides a successful example of enforcement, using the sanction of suspension of trading. Since suspension powers were given to the BMV, delivery of information has improved from 30 cases of non-fulfillment of requirements of quarterly information (1999) to less than 3 (2002).

A particularly problematic ownership structure involves the use of nominee accounts, or offshore companies, to completely obscure the identity and exact holdings of the ultimate owner. Two examples, of Russia and Malaysia, illustrate the problem, as well as a solution, respectively. The Russian market is characterized by the presence of financial and industrial groups. Major stakes in most companies are held by offshore companies located in jurisdictions such as Cyprus, British Virgin Islands, Jersey, Guernsey, etc. They typically have nominee directors and nominee shareholders, which makes it practically impossible to determine their beneficial owner. They further typically own small enough blocks to just avoid disclosure regulations. ${ }^{39}$ Further, major transactions with shares in Russian companies generally take place between offshore sellers and offshore buyers and as a result fall largely outside of reach of Russian authorities. In contrast, disclosure of nominee accounts improved in Malaysia since 1998. Reflecting its UK legal history, nominee accounts are common. At the end of 1997, nominees represented the largest type of shareholders among the top five shareholders, owning 45 percent of all PLCs. About 85 percent of the PLCs had owner-managers; the post of CEO, chairman of the board or vice-chairman belonged to a member of the controlling family or a nominee. ${ }^{40}$ However, in 1998, amendments to the Securities Industry (Central Depositories) Act 1991 introduced the authorized nominee concept, prohibited omnibus accounts, and obliged the beneficial owners to reveal their identity, with palpable results.

Another important piece of information that companies should disclose is material events. Those are important transactions or news, usually technically defined as "significant enough to move the stock price of the issuer". In Romania, ownership disclosure provisions are poor both by law and in terms of enforcement. There is no access to the full details of annual reports and no standardized annual report format. The companies do not disclose composition and remuneration of Boards

\footnotetext{
${ }^{39} 20 \%$ would trigger antimonopoly rules.

${ }^{40}$ Fazilah Abdul Samad, Ph.D, "Malaysian Corporate Governance Environment and Policy and their Impact on Corporate Performance and Finance" RETA 5802, November 1999).
} 
and key executives. Share class details and voting power are also not available. Related party transactions are not publicly announced. The CNVM reviews and enforces the disclosure of some items; however this is done more with an eye to quantity than quality of information. of disclosure content. Publication of real-time disclosure in the Official Gazette is often delayed by up to two months, and obtaining copies is considered to be relatively expensive. The Colombian Superintendency of Securities shows more assiduity in enforcing transparency, and that is also the most common petition brought before the regulator. For example, when Terpel Sur S.A., a distributor of gas and other fuels, requested shareholder approval to sell all its operational assets to its parent company, the Superintendency compelled the provision of additional information at the complaint of minority shareholders. A similar request was again granted when Inversiones Nacional de Chocolates S.A., an industrial food and candy conglomerate, planned a spin-off of its investment activities. In the Philippines, transparency enforcement has increased at the instigation of the court, more so than the SEC. A mere 5 years ago, there was strong resistance by management to give out material information to minority shareholders. For example, out of 246 listed firms, the SEC uncovered failure to disclose material information in 55 issuers in 1999 and 60 in 2000. In response, trial courts have virtually uniformly decided for plaintiff upon minority shareholders petitions for detailed information from management. As a result, managers are more careful with their decisions, and undertake to document their actions more extensively in an effort to demonstrate proper compliance.

\section{Section III. What Works To Enforce Minority Rights}

One of the earliest and most pervasive solutions to the corporate governance problem is regulation. Investors, and in particular shareholders, enjoy protection from parties in possession of corporate control, via listing regulations or in the corporate and securities laws. For example, regulation includes simple, easy to enforce rules, such as (1) minority dividenes, such as (1) minority dividen rights to elect a director; (2) takeover rules (equal prices, tag-along rules, freeze-outs), and (3) oppressed monitory mechanisms (Section 3.1). In addition to regulation, other mechanisms have been used to cope with the issues of corporate governance, requiring the initiative of minorities themselves. First, shareholders can act through the board, or the board itself can enforce minority rights. Second, AGMs can adopt resolutions protecting the minority, and approve certain important company actions. And third, shareholders can file their complaints to the Securities Regulator or the court, in 
their defense (Section 3.2). Finally, third parties can help enforce minority rights, such as creditors, institutional investors, auditors, media, reputation, and social pressures (Section 3.3).

\subsection{Regulation mandating minority protection}

3.1.1. Minimum dividends are appropriate for poorly-developed capital markets; pre-emptive rights and minority rights to elect a director come into play at mid-level stages of market development.

Mandatory dividend pay-outs are meaningful in poorly developed capital markets where issuers do not feel pressured to provide expected returns as they are unlikely to return to the market for funding. In Chile and Colombia, a minimum of $30 \%$ and $50 \%$ of net earnings needs to be paid out as dividend, respectively. ${ }^{41}$ Minimum dividends are mandated also in the Philippines, Ecuador, and Uruguay. As markets develop and issuers interact with investors more actively, the need for such provisions disappears. Accordingly, the rule is not present in South Africa, Poland, or Thailand. In Lithuania the rule on mandatory dividend at $50 \%$ of profits was eventually repealed as it was never used, since shareholders typically agreed with the dividend proposed by management. In Peru, the mandatory dividend right is rarely used, though needed, due to the high shareholder action threshold of $20 \% .{ }^{42}$ In Brazil, shareholders frequently engage in voting disputes and disputes on the calculation of dividends, based on the minimum dividend provision, as well as the rule that non-voting shares receive a right to vote if dividends have not been paid for 3 years.

Ultimately, the need for a mandatory dividend provision needs to be assessed in view of the local conditions in the country. In Argentina, private action is sufficient to assure minority rights, and no mandatory dividend rule is in force. Dividend payment disputes are nevertheless common, as shareholders challenge the declared negative net income on the grounds that it was understated with a view to avoid a dividend payment. In contrast, neither private action nor regulation by law would help some Russian companies' preferred shares receive their due dividend value. In spite of mandatory dividend rules in Company Charters, corporate earnings are

${ }^{41}$ The threshold can be decreases with supermajority at the AGM. Fremond / Capaul.

${ }^{42}$ LGS, article 231, pub. 9.12. 1997. 
manipulated leading to lower declared dividends; and further actual pay-out is delayed or forgotten. An illustration of the issue is a series of lawsuits from early 2001 to March 2004 (most recently) by minority investors against Surgutneftegaz, the $2^{\text {nd }}$ largest oil company, of concealing profits and underpayment to privileged stock. The management has "parked" more than $60 \%$ of the votes of the company with subsidiary firms, and de facto yields control with less than $1 \%$ ownership. As a result, Surgutneftegaz traditionally pays extremely low dividends and per minority stockholders assertion wastes significant resources on fruitless explorations and sells oil at lower than market prices through intermediaries.

Pre-emptive rights give minority shareholders the option to avoid dilution of their share value by increasing their stake in proportion to the increase of the majority stake, when new shares are issued. Such rights exist in Russia and Thailand, among others, and are usually waived only with a majority or supermajority. In Peru, however, it is possible to waive pre-emptive rights with a mere $40 \%$, provided this percentage constitutes a majority of the votes at a shareholders meeting. ${ }^{43}$ Bulgaria adopted pre-emptive rights in 2001. As a result, the widely spread practice of majority owners to increase unilaterally their capital by relying on the lack of participation of minority shareholders in new equity issues, was curtailed. ${ }^{44}$

Cumulative voting afford the minority the ability to elect at least one representative on the Board of Directors, by staking all their votes behind that candidate. Cumulative voting is mandatory by law in Argentina, Philippines, Poland, and Russia, for example, and optional in Bulgaria, Chile, Croatia, Latvia, and Slovenia. In Korea, $1 \%$ of shareholders can request that cumulative voting be used, but a supermajority can avoid this provision, and $80 \%$ of listed firms have done so. Proportional representation rules have a similar effect, whereby a given percentage of voting rights has the right to appoint one director. Proportional voting is present in Colombia, Mexico and Brazil.

In Romania following privatization, corporate control was acquired by strategic investors, who were reluctant to pay dividends. As a remedy, the 2002 revisions to the Securities Law introduced the possibility of cumulative voting: ${ }^{45}$ mandated the

\footnotetext{
${ }^{43}$ LGS, Article 259.

${ }^{44}$ Atanasov, Ciccotello and Gyoshev, "An Empirical Examination of Law, Freeze-out, and Tunneling in an Emerging Market", 2003.

${ }^{45}$ Ordinance 229/2000 (now repealed).
} 
payment date to fall within at most six months of the AGM, and within 60 days of the publication of the AGM decisions; and endowed the AGM decision with the power of a writ of execution, based on which the shareholders may begin the enforcement procedures against the company. ${ }^{46}$ The cumulative voting measure was later repealed, as it proved inadequate to ensure dividend payment, though legal professionals suggest that a simple rule on minimum dividend may have been successful. The CNVM is expected to issue further regulations regarding cumulative voting in 2004.

\subsubsection{Sharing value with the minority at control changes: equal prices, tag along, freeze-outs.}

Corporate control changes hands typically at a premium in emerging markets, on average $14 \%$ around the world. ${ }^{47}$ Control values range from less than $2 \%$ in Australia, Canada, Japan, South Africa, the UK, and the US, to more than $25 \%$ of the value of the firm in most European, East Asian, and Latin America countries. A large part this premium reflects the private benefits that controlling shareholders enjoy form the company, as suggested by the fact that better laws and stricter enforcement explain $75 \%$ of the cross-country variation in control premia. ${ }^{48}$ Mechanisms that provide for the minority common shares to receive the same price as the one paid to the controlling block; tag-along rights for other classes of shares upon a change of control, fair price for frozen-out shares, and dissenting shareholder rights assure that the minority investors share some of the gains from change in control with the majority owners. Such sharing has a negative effect as well: it makes control changes costlier, thus potentially decreasing takeover activity. The market for corporate control and proxy fights as corrective mechanisms have a limited to no effect, and are unlikely to be important when ownership is strongly concentrated, especially in developing countries where hostile takeovers are rare. This is why it is not so harmful to lower the incidence of changes of control, in the interest of sharing some of the control benefits with the minority. The case of Backus (Peru) illustrates the reluctance of controlling owners to share benefits with the minority. In 2003, Bavaria (controlled by the Colombian Santo Domingo family) dividend one substantial acquisition (of Backus) into two transactions, each

\footnotetext{
${ }^{46}$ Securities Law $\$ 114$.

47 Dych and Zingales 2002 examine 39 countries.

${ }^{48}$ Nenova (2002).
} 
one slightly below the $25 \%$ trigger, in order to avoid the mandatory tender. In the end, the matter was settled between the parties without a CONASEV ruling.

The takeover attempt in 1997 of Chile's largest private energy sector holding company, Enersis S.A, by Endesa España (Spain) is a landmark case in minority shareholder rights. In 1997, Enersis S.A was controlled at $32 \%$ by five investment companies (the "Chispas"). Chispas B (voting) shares concentrated a large amount of voting power and less than $1 \%$ of the capital of Enersis S.A, and were owned by former employees and management. The A (non-voting) shares were held mostly by pension funds and employees. For the purpose of acquiring control, Endesa España created a strategic alliance with Enersis' management, promising them guaranteed positions for 5 years. Enersis executives applied pressure and influence to encourage employees to sell their shares. The tender offer sought B stares at USD 253.34 plus 5 Endesa options at discounted prices, and A shares at USD 0.30. The AFPs argued that the benefits of the tender were too unevenly distributed and that pressure was being placed on those who chose not to accept the tender for A shares, and eventually succeeded in having the tender voided. When finally Endesa acquired control, Enersis' former controllers had been legally ejected. ${ }^{49}$

${ }^{49}$ Source: Chile ROSC. 


\section{Box 2 \\ Chile-continued commitment to reform}

The Securities Market Law and the Corporation Law form the legal framework governing listed companies. Although the Chilean legal system follows the tradition of French civil law, these two laws were strongly influenced by U.S. law and practice. Their main body was passed in 1981 and amended in 1989 and 1994. In 2000, both laws were overhauled by Law No. 19,705, known as the Corporate Governance Law or Ley de OPA, to the effect of a palpable improvement in Corporate Governance in the country. The Securities Market Law was amended again in 2001 to deal with the administration of voluntary savings. A planned follow up, increasing flexibility for private companies, is pending Congress approval in 2004-5. The creation of private arbitrageurs under the Cámara de Sociedades Anónimas and through special co Chile's takeover law ended up incorporating other governance provisions as well. The bill took 3 years to pass, with the active support of who heads of Superintendencia de Valores y Seguros (SVS), Daniel Yarur and Alvaro Clarke. The law provides (1) any block purchase at a premium higher than $10 \%$ should include a pro-rata purchase from minority shareholders; (2) any owner of $67 \%$ of capital should launch a mandatory tender offer for the remaining shares at tha same price as the block purchase; (3) mandatory audit committees for larger listed firms, with 50\% independent members; (4) mandatory independent directors on all boards; (5) minority shareholders can sue the majority for conflict of interest or fraud; buy-backs are limited to $5 \%$ of capital; stock options as a form of compensation to employees is introduced. Disclosure requirements for tender offers were considerably strengthened as well. The SVS introduced stricter financial reporting requirements in 2001 as well. The SVS redesigned the quarterly reports that all publicly traded companies must file, in order to increase the quality and quantity of public information. The new design follows US standards, so many of the larger Chilean companies with ADR programs are already used to providing this type of information is also underway.

Source: Chile ROSC.

The reforms of takeover provisions in Brazil are a case in point. Originally, the Corporation Law required that in a change of control, the acquirer make a tender offer for all common (ON) shares at the same price. There were no tag-along rights for non-voting (PN) shares. In 1997, to ease the privatization effort, the equal pricing provision was repealed. The issue has been hotly debated ever since. The CVM attempts to re-introduce the measure, be it through law or CVM 
Ordinance, have failed; 50 in fact, one of the most contentious issues of Law 10,303 was whether this right should be restored. A compromise was reached that ON shares receive $80 \%$ of the share price paid to the controlling group. ${ }^{51}$ Since CVM Regulation 358/2002, the price of a control block trade is disclosed. Evaluations, appraisal reports at control change, tag along rights are often the subject of lawsuits. The case of Lojas Renner in December 1998 is one instance where the CVM forced the majority holder of Lojas Renner, JC Penney, to offer a higher price for a buy-back offer to non-voting shareholders.

A look at the quality of takeover provisions across countries reveals the following major points. ${ }^{52}$ The takeover laws with highest minority protections are in Canada, South Africa, Hungary, Hong Kong, and Mexico. The least minority-friendly laws are in Brazil, Egypt, South Korea, Ukraine. A word of caution for precedent-based jurisdictions such as the US and the UK, which protect minority investors adequately, though this fact is not obvious from the letter of the law.

In the case of de-listings, the new law gives minority shareholders of both classes the economic value inherent in their shares, based on an independent appraisal. Prior to 2001, going private transactions in Brazil were popularly associated with an expropriation of dispersed (mostly non-voting) shareholders, as the controlling entity lowers firm performance (and share prices), and gradually buys back shares, thus reducing liquidity and further depressing share prices. Delistings are frequent in capital markets, especially in poorly developed emerging markets. Since 1997, for example, 179 securities have been de-listed in Peru ${ }^{53}$ and many more are expected to do so in the future. An efficient and equitable form of a freeze-out is thus needed.

The case of Sopharma (a Bulgarian blue chip) illustrates the potential for direct self dealing by controlling shareholders during minority freeze-outs. The freezeout is a right of the controlling shareholder, upon accumulating a very high share of

\footnotetext{
${ }^{50}$ CVM Instruction 299/1999 re-introduces the mandatory offer for the minority shares (of either class) upon an increase of $10 \%$ or higher in the same class; however, the minimum purchase price equals at least book value.

${ }^{51}$ Companies listed on Nivel II ( $8 \%$ of all listed firms) must offer $100 \%$ of the control block price to ON shares, and $70 \%$ of that price to PN shares. The two firms listed on the Novo Mercado grant full equal price and tag-along rights to $\mathrm{ON}$ and $\mathrm{PN}$ shares.

${ }_{52}$ Takeover rules are overviewed and indexed in "Acquisition Rules around the World", Tatiana Nenova.

${ }^{53}$ Statistics from the BVL, January 2004.
} 
company capital (usually around $90 \%$ ), to oblige all outstanding shares to sell, in order to de-list the firm. Freeze-out provisions safekeep majority shareholders from haggling minorities; however, the minority should be protected against being forced to sell the shares for peanuts, as the controlling owner dictates all decisions in the firm, including those requiring supermajority. "In the summer of 2000, Elpharma, a rival pharmaceutical company, purchases $67 \%$ of the shares of Sopharma from the Bulgarian government for the price of $\$ 7$ a share. ${ }^{54}$ In early December 2000 , Elpharma, directs its controlled company, Sopharma, to issue shares at $\$ 1$ (the market price at that time is \$13). Elpharma relies on the passivity of the minority and obtains most of the newly issued shares, to a total stake of $86.65 \%$. Aside from foreign funds, minority shareholders including the Bulgarian Government (with an $18 \%$ stake) do not participate in the new issue. In a matter of days after the secondary issue was completed on January 15, 2001, the price of Sopharma drops from 13 to $2.5 \mathrm{BGN}$, a decrease of $81 \%$. Soon afterwards Elpharma announces a tender offer for the remaining shares. SSEC rejects the offer applications due to its low price and clear intent to expropriate minority shareholders. In December 2001, the new securities law introduces pre-emptive rights and minimum price provisions in tender offers and freeze-outs. Elpharma abandons the tender offer attempt. As the potential for further expropriation of minority Sopharma shareholders is lowered, the stock price grows by about $100 \%$ in two weeks (from $\$ 2$ to $\$ 4$ ). ${ }^{55}$

\subsubsection{Oppressed minority mechanisms: dissenting shareholder rights, audit at company expense}

Oppressed minority mechanisms allow investors to sell their shares to the company at a "fair" price, upon disagreement with a major corporate decision, such as a substantial asset sale, change in the founding documents or the company purpose. Such right of redemption exists, for example in Korea and Mexico. Colombian shareholders can "put" their shares to the company, if they do not agree with (a limited number of) fundamental decisions. ${ }^{56}$ The put price is "fair

\footnotetext{
${ }^{54}$ New shares, the price is $\$ 38$ as the shares were split subsequently $5: 36: 1$.

${ }^{55}$ Atanasov, Ciccotello and Gyoshev, "An Empirical Examination of Law, Freeze-out, an Tunneling in an Emerging Market"

${ }^{56}$ Derecho de retiro applies in the case of mergers, spin offs or transformations. Article 12 of Law 222 of 1995 . The new securities bill proposes to expand decisions where withdrawal rights apply to include sale of substantial assets.
} 
market value" as determined by an independent expert appointed by the chamber of commerce.

In Mexico and Croatia, shareholders with $10 \%$ of the capital can name a statutory examiner, regardless of the kind of shares they hold. In Romania, 25\% of the shares can request the censors (examiners or fiscal boards) to present their conclusions to the AGM, and $10 \%$ can ask court to appoint expert to examine certain operations. ${ }^{57}$

\subsection{Private Enforcement of minority protection}

Minorities have a number of avenues for redress by law. First, they can complain to the Board of directors, as in India, where an "investor grievance committee" of the Board, mandated by law, meets once every quarter to consider redress, shareholders rights, and investor complaints, and reports to the AGM annually. ${ }^{58}$ Second, usually $5-10 \%$ of the capital can call an AGM to vote on the issue of discontent. Even in majority controlled companies where the vote would turn unsuccessful, AGMs can take the issue into the public attention and create pressure on management. A related mechanism that may further minority protection is the rule to subject related party transactions to AGM approval, as in Chile, where a $5 \%$ minority can request that an RPT be approved at an ESM. ${ }^{59}$ Third, shareholders can take their complaint to the Securities Supervisor, as is often done in Brazil and Russia. And finally, they can go to the courts, as is popular in Lithuania, where courts are reasonably quick and efficient, or to the rarely available alternative of arbitration, as in Chile. Channeling minority private actions through the Securities

Supervisor has the advantage of specialized knowledge, better resources, as well as superior information on securities and listed company issues. The court, on the other hand has wider enforcement powers: they can levy civil and criminal penalties, as well as request evidence from a wide set of sources, summon witnesses, and enforce decisions. The choice of enforcement mechanism should be made in

\footnotetext{
${ }^{57}$ Fremond / Capaul

${ }^{58}$ Clause 49, Section VII(F) (iii).

${ }^{59}$ Fremond / Capaul
} 
accordance with local conditions. Russian courts are rarely used, as the likelihood of success is very small and favorable judgments are not enforced even if obtained. In China, however, the litigation route holds some promise. ${ }^{60}$ A typical set of shareholder redress regulations is described in Box 3 on the example of Peru.

\section{Box 3 \\ The theory and practice of court minority redress in Peru}

In theory, shareholders have broad legal venues for redress: $20 \%$ of capital can call an AGM (in an SA, this percentage is $5 \%$ in an SAA, $\S \S 117,255$, LGS); $25 \%$ can postpone the AGM; $25 \%$ confer rights to information (in an SAA, $5 \%$ in an SAA, $\S \S 130,261$ ); $20 \%$ suspends a contested AGM resolution; $20 \%$ request the forced payout of half of annual earnings as dividend (§145). Withdrawal rights exist in cases where shareholders vote against certain fundamental decisions or are not present at the AGM (\$200). A direct suit by a shareholder against the company or a director can be brought only in a limited set of circumstances. A derivative suit on behalf of the company is filed with $33 \%$ of capital, against a director or the board as a whole; sums recovered do not go to the plaintiffs; however, but the company. A proposed amendment to class actions will allow their usage to solve shareholder disputes $(\S \S 12,13,139,181,182)$.

The practice, however, is very different. There have been very few actions of corporate or individual claim against the board, due to the high capital thresholds, the difficulties in obtaining information and in proving fraud, abuse of power or gross negligence, and the lack of specialization in the judicial branch and the high costs of long trials. The few cases that did take place were cases of fairly obvious fraud. While arbitration is permitted, it is not widely used and some bylaws expressly prohibit it. Most actions brought before the judiciary relate to shareholders meetings, e.g. failure to publish the agenda or voting on items not listed in the agenda. In such cases the evidence required is fairly straightforward and these cases tend to be solved more expeditiously, usually in favor of the plaintiffs

${ }^{60}$ Zamulin and Zhuravskaya, 2003, Pistor and Xu, 2003. 


\subsubsection{Board actions: independence and audit committees}

In countries with concentrated ownership, a requirement for independent directors is ineffective. "The board of Indian companies[...] are invariably filled with family members and friends, whether or not they are qualified for the position. In such an environment, the promoter can operate to further his own interests even as he takes the other shareholders for a ride." ${ }^{61}$ Independent directors are widely advocated in industrialized countries as a means to protect the rights of shareholders. In poorly developed markets, however, the business community is sufficiently small that financial and personal interests interlock, as is the case in the Philippines. In such countries, independence requirements are likely to be of little effect, though onerous. For example, a poor Romanian professor, paid $\$ 1,000$ per board meeting, cannot be expected to risk this considerable source of income in exposing insider dealing. An additional problem, particularly strongly expressed in Asia, is the underlying culture of consensus, coupled with owner/manager dominance of the boardroom. Independent directors constitute $34 \%$ of Hong Kong Boards. However, it is always difficult to find experienced and devoted directors, and most new appointees do not usually know enough about the realities of business to effectively monitor inside executive directors. According to a survey by the Hong Kong Institute of Company Secretaries in 2002, less than $40 \%$ of directors understand their fiduciary duties and legal responsibilities, and the rest give them low priority. In fact, the role of a director is sometimes mixed up with that of a senior manager. Due to concentrated ownership, independent directors are often nominated by executive directors who represent controlling shareholders, who in turn hold the key votes to elect and replace the "independents". The case of minority shareholders remains unstated; at signs of insider dealing, independents may simply resign early to avoid liability. Further, real outsiders are usually not trusted, and friends or close contacts of the controlling family fill the independent director slots. ${ }^{62}$

Finally, even in capital markets at mid-level of development, independent directors may not have real power, as the controlling owner can hire and fire board members, and the pool of qualified directors is small. This is not to say that rules on

\footnotetext{
${ }^{61}$ Financial Times Asia Intelligence Wire, October 10, 1999, quoted in Bertrand, Mehta, and Mullainathan,

"Ferreting out Tunneling: An Application to Indian Business Groups.", 2000.

${ }^{62}$ Ho, 2003, "Corporate Governance in Hong Kong: Key Problems and Prospects"
} 
independence are not justified for moderately developed markets. First, independent directors can raise awareness for suspected wrongdoings and for reform. And second, full wielding of independence powers will be achieved in time; however, policymakers should be prepared to reasonably expect a positive change only in the medium to long term, as training and strengthening of duties and liability bring desired results. For example in Chile, where independent directors are mandatory, the attractive director pay had prompted some "independent" parties to make their living as Boardmembers, appointed by the minority. In the past 8 years, however, director liability has become a concern, and following some standard-setting legal cases, director independence has considerably strengthened. Director fiduciary duties and liability is the core legal concept to address conflicts among directors/ managers and shareholders. It is more easily implemented in common law jurisdictions such as South Africa than in civil law ones, since the latter typically lack the necessary procedural rules, or have not developed a sufficient body of case law to determine the contents and meaning of this concept. In a study of the statutory and case law in Poland, Russia, and Germany on matters that would fall within the scope of fiduciary duty in Anglo-Saxon countries, it is evident that case law is scarce, even in Germany, a highly developed market economy with extensive experience with corporations and corporate law. ${ }^{63}$ Director liability requires efficient courts and strong judgment enforcement, which is not the case in most poorly developed (or even mid-level) emerging markets. For example, courts in transition economies are widely perceived to be weak, inexperienced, or even corrupt. ${ }^{64}$

\footnotetext{
${ }^{63}$ Pistor and Xu, "Fiduciary Duty in Transitional Civil Law Jurisdictions: Lessons from the Incomplete Law Theory", 2002.

${ }^{64}$ Black and Kraakman 1996; Glaeser et al., 2001.
} 


\section{Box 4 \\ Brazil and Russia - two paths to director independence}

Most board members are shareholders of the controlling group or individuals representing their interests. They meet sporadically and do not devote sufficient time to their responsabilities. Management is either strongly influenced by the controlling shareholder or the latter is the chief executive officer himself. The first step towards independence of directors was the creation of a fiscal board, to which a minoirty can elect a member $(\$ 161$, corporation Law 10,303). Tha fiscal board is not necessarily permanent, its members are not directors of the board, and the controlling shareholder appoints the majority of its members. Per civil law tradition, fiscal boards have potentially wide powers to supervise management, oversee financial reports, examine accounts, consult with external auditors, issue opinions on the annual report and major corporate transactions, report criminal acts, and call the AGM ( $\$ 163)$. However, according to market analysts, fiscal boards have been largely ineffective. In 2001, the powers of individual fiscal board members were strengthened, by requiring the publication of the opinion of the fiscal board, including dissident votes $(§ 133)$. Currently, the minority can choose one of three board candidates proposed by the Controller. Starting in 2006 , a $10 \%$ minority would both nominate and elect their Board representative, who will have the additional power to veto the appointment of the auditor $(\$ 141)$.

The first independent directors appeared in the boards of Russian companies after the 1998 crisis when foreign portfolio investors suffered heavy losses because of expropriating actions of managers and major shareholders. The investor and brokerage companies which represented these investors spearheaded the campaign for electing independent directors to companies in which they held stocks. These companies nominated and voted their candidates in through the Investor Protection Association (IPA) and its affiliate Independent Directors Association (IDA). In 2001, IPA representatives were elected as independent directors to the boards of 38 companies and in 2002 to the boards of over 50 companies. Yet, the problem with these directors is similar to thah with the board members: allegiance to a particular group of shareholders - in this case, to those portfolio investors who have voted for thier election. In addition to this category, there is a number of outside directors who are not affiliated with the IPA/IDA. Some of them are prominent experts in business or former senior government officials, others are executives of major business groups wich bought minority stocks in the appropriate companies. Since 2001, a new trend could be seen among the major Russian companies: to elect prominent foreign businessmen as independent directors to their boards with the votes cast by the controlling shareholders. Over tha last three years audit commissions were set up in a very small number of major Russian companies - Yukos, LUKoil, United Heavy Machinery, though some of these audit committees include executive directors. The ability of non-executive/independent directors to obtain relevant information on time fully depends upon the behavior of company top and senior management, though over the last 3 years the situation has improved. Rubber-stamp boards are still widespread, especially in middle-size and small firms.

Source: Russia and Brazil ROSCs 


\subsubsection{Annual General Meeting (AGM) powers in defense of minorities}

In Mexico, where average AGM attendance is $93 \%,{ }^{65} 10 \%$ of any class allows minorities to protest against improper conduct of an AGM, including provision of insufficient information. This right is often used, for example recently by the shareholders of SIDEK to nullify an extraordinary meeting that was impromerly summoned. In some countries, however, it is harder to call an AGM due to the excessively large minority required for action $-20 \%$ in Colombia, or $15 \%$ in Jordan. ${ }^{6}$ In the Philippines, shareholders do not currently have the right to convene an AGM, and the company is not required to provide notice to shareholders. Neither do minority shareholders have the right to put forward resolutions to the agenda which are circulated to other shareholders at the company's expense.

\subsubsection{An effective minority recourse: Securities Supervisor versus court.}

In spite of strong provisions in the Law on Securities Market, the investigative power of the Georgia's NSC has been limited by a lack of clarity on the procedural rules for investigations and as a result, the NSC has not been able to launch any formal investigations of violations of securities or other laws. In 2000 , only $38 \%$ of all reporting companies filed annual financial reports with the NSC. As much as $80 \%$ of joint stock companies in Georgia fail to hold regular shareholders' meetings. ${ }^{67}$ There is no disclosure on ultimate ownership nor related party transactions. All enforcement actions require decisions by the overburdened court system of Georgia and to date, there has been no enforcement. The situation is only slightly better in Morocco, where the $\mathrm{CDVM}^{68}$ cannot fine or sanction listed firms without court involvement, and up until 1995 auditors did not need to be chartered accountants. ${ }^{69}$ Takeover laws are largely nonexistent, and RPT and insider trading laws are weak This section discusses the optimal enforcement powers of the court and the Securities Supervisor, and illustrates best practice as well as inefficiencies observed around the world.

\footnotetext{
${ }^{65}$ As of April 2002. Source: Mexican Stock Exchange.

${ }^{66}$ Fremond/Capaul

${ }^{67}$ Estimate of the Georgian Securities Industry Association, which largely represents brokers.

68 "Conseil déontologique des valeurs mobilières"

${ }^{69}$ Article 160 of SA Law $17 / 95$ introduced that requirement.
} 
Egypt listed firms are under the authority of several agencies with overlapping jurisdiction, which weakens law enforcement. The Capital Market Authority (CMA) is the securities market regulator, reporting to the Minister of Foreign Trade. The Companies Department at $\mathrm{GAFI}^{70}$ supervises the enforcement and implementation of company law. CASE, the Egyptian stock exchange, is a quasi-governmental body under the supervision of the CMA. Besides independence, the CMA lacks strong powers and enforcement capacity. The courts are likewise of limited effectiveness in securities cases. As a result, minorities or the CMA rarely initiate an action, and the few CMA cases are likely reversed on appeal at court. In Romania and Indonesia likewise, both the courts and the securities regulators are weak. Indonesia's BAPEPAM lack independence as well, but it has been making its first successful steps as an effective regulator in the past 10 years. Romania's CNVM lacks resources and training, and mostly monitors the timeliness of filings, as well as the conduct of AGMs and the implementation of AGM resolutions. Therefore minority complains are mostly addressed to the courts, in spite of their inefficiency. Studies have found the regulator to be most effective when it has adequate powers, is well-staffed, and of particular importance, has operational and financial independence. Though regulators have their own income sources, for example from fees and fines, they may have to transfer some part to the general budget or otherwise have their budget approved by the parliament or other government agencies, thus reducing their de-facto independence. Insufficiently strong powers of enforcement can also be a bottle-neck.

${ }^{70} \mathrm{GAFI}$ is the General Authority for Investment and Free Zones. 


\section{Box 5 \\ Gradual increase of enforcement powers in line with capital markets needs}

\section{First steps to enforcement for Indonesia's BAPEPAM}

BAPEPAM is criticized for excessively low fines administered, lack of investigation capacity and of a surveillance system linked to JSX, and leniency in enforcement on large firms. In addition, it is structurally under the MoF and is heavily dependent upon the government budget. A succesful first step to tackle these issues was taken in 1995, law and procedure of investigation was finally set up, and 20 new officers were added in 2001 to the investigation department. Unused avenues for investigation remain, for example JSX and BAPEPAM could check insider or false transactions through the Central Security Depository Institution. Even given its current powers and capacity, BAPEPAM imposed in 2002: 246 fines totaling IDR 20,578 billion; 10 revoked financial firms business licenses; 33 financial firm and 4 public accountant suspensions; and 35 written admonitions. On the other hand, minorities have used their court action only 10 times in the past 20 years, as courts are slow an incompetent in securities matters. BAPWEPAM has likewise rarely brought a case to court successfully.

Hungary's BSE achieves a larger enforcement role since 2001

BSE used warnings and fines, in the past 5 years, mostly on disclosure issues. For example, an insider trading penalty in 2001 was awarded to OTP Bank Rt. (\$2000), OTP Security Rt. (\$1200), and OPT Bank Rt's deputy CEO (\$800) who had traded OTP Bank shares shortly before the release of its financials. BSE needed to complement its weak powers with informal enforcement means. For example, in early 2001 Aragó took over Pick, a large food company, and under-stated subsequent earnings in preparation for tendering for Pick's shares. PSZÁF applied pressure with various means on the owner of Aragó and managed to reach a fair price on the tender. However, BSE's powers for enforcement of disclosure requirements and licensing were significantly boosted with the Capital Market Act amendment of July 2001. The reform was provoked by the attempted closet takeover of the Hungarian petrochemical campany Borsodchem by Russia's oil company Sibur (owned by Gazprom), via a complex acquisition of undisclosed small stakes through Irish and Austrian companies, with hidden agreements in the background; as well as through a call option on the shares bought by a Hungarian bank assisting Sibur. PSZÁF took measures to avoid the majority control gain, as it went to court against the bank for non-prudent behavior and won the case.

South Africa - the FSB is getting advanced-level enforcement powers

Despite the efforts made by the FSB, its actions and powers remain in fact relatively not dissuasive. Its main repressive action remains administrative: de-listing of some companies, warnings towards brokerage companies and mutual funds managing companies. This is the reason why the law governing the FSB is projected to be amended in order to give more power to the FSB. The bill will be presented to the Parliament in 2004. 
At low levels of capital market development, Securities Supervisor powers are most efficiently focused on enforcing disclosure, as well as addressing major tunneling problems. Excessive enhancement of regulator powers can have perverse effects in institutional environments with weak checks-and-balances such as in many developing countries. ${ }^{71}$ Russia's FKSM powers, in the opinion of some market participants are very strong in practice, to the level of being counter-productive. ${ }^{72}$ Hungary strengthened the BSE enforcement powers successfully in 2001 (Box 5). South Africa's efficient litigation system for minorities was further simplified by introducing a new derivative action procedure. ${ }^{73}$ In line with this development, the powers of the CDVM are projected to be further strengthened closer to the level of the US SEC (Box 5). Overall, however, it is safe to conclude that in the specific context of emerging markets, where courts tend to be slow and ill-experienced, private enforcement, as by a securities regulator, is particularly efficient. ${ }^{74}$

Securities regulators do not always make full use of their powers, as is the case with the Argentinean CNV, which has played a very passive role. The CNV has been flexible in allowing companies to remain listed. It has avoided taking sides in minority court actions, e.g. to testify as a third party in shareholder disputes, especially having in mind the lack of judge familiarity with securities issues. CNV's passivity comes in the context of an anyway overburdened judicial system where disputes take 3-5 years. In Brazil, in contrast, the CVM has actively used its powers, frequently testing their limit. Minorities actively file with the CVM, and seek court recourse only as a final option. Specialization and jurisprudence are poor in state courts. Final decisions take years, and the aggrieved party may incur substantial costs. Court cases are invariably settled before resolution. Hong Kong's SFC wields wide powers, including the promulgation of securities regulations. It does not enforce its own rules diligently, however, and lacks the power and will to tackle big market players. In 2002 out of 391 new cases under investigation, only two were referred to the Police's Commercial Crime Investigation Bureau, and only 37 people were successfully prosecuted in that year.

\footnotetext{
${ }^{71}$ Barth, Caprio and Levine, 2000.

${ }^{72}$ Corporate Governance in Russia: An Investor Perspective, Institute of International Finance, November 2002.

${ }^{73}$ S252 of the Companies Act.

${ }^{74}$ Black and Kraakman (1996) and Hay, Shleifer, and Vishny (1996).
} 
There is a certain substitutability of the function of the Securities regulator and the courts. In Lithuania, the courts function well enough as to render the choice of the extent of securities regulator powers unimportant (Box 6). In Slovenia, in contrast, it takes 1-2 years on average to obtain a hearing at Slovenian courts, and 3 more years to have the judgment enforced (e.g. through seizure and sale of property). Since 1998, there have been on average 500.000 new cases filed per year. Romanian courts are weak as well, but minorities nevertheless recourse to courts in the absence of a strong CNVM (Box 6). India, on the other hand, improved the functioning of the courts trying securities cases, as it creates the National Company Law Tribunal (NCLT) in replacement of the existing CLT, a specialized court on company matters, itself created in response to the High Court's inefficiency in the early 1980s (when disputes reputedly lasted between 6 and 20 years). The NCLT will have 10 benches around the country as opposed to CLT's 4, and appeal at the High or Supreme Court is limited purely to questions of law (not facts). This is expected to further reduce the current duration of commercial litigation (3-5 years).

Courts are crucial for the enforcement capabilities of securities regulators, especially in terms of collection and criminal (and sometimes civil) charges. The Thai SEC is successful in identifying misreports, insider trading, self-dealing, and manipulation of data, as well as in enforcing high standards of accounting and disclosure. SEC can impose fines; however, when it comes to filing action, enforcement fails. For example, there've been no successful cases of insider trading prosecuted to a concluding sentence, due to inefficient, overburdened, and poorly trained general courts. Court has ruled contrary to SEC testimony, as stringent proof standards have been impossible to satisfy in insider trading and self-dealing cases. SEC fines can be disputed at court, abusing the latter's slowness and case record of denying insider trading and self-dealing charges. The situation is similar in Turkey (Box 6). 


\section{Box 6 \\ From weak to strong courts - Romania, Turkey, Lithuania}

Romania - a weak SEC pushes minority actions to overburdened courts

Essebtially all litigation is brought by institutional, not retail investors. Usual complaints include: dispute of the AGM resolution, disclosure and non-market terms of contracts between realted parties; terms of substantial asset sales; profit (dividend) distributions. The capacity of the courts is weak, and the case load - enormous, so litigation lasts months or even years.

Upon shareholder request or on its own instigation, CMBT conducts an investigation and prepares an audit report, based on which potentially CMBT brings the matter to a public prosecutor. The public prosecutor's office has three options: bring the case to the court, mandate a fine without opening a court case, and reject the matter for lack of violation. The latter option is used in more than half of the cases, and a more fine is imposed in another 35\%. Between 1994-8, there have been only 3 cases of a completed court trial, demonstrating a severe operational problem in the legal process. RPT, a particulary acute problem in Turkey, are thus not prevented, as the most that CMBT can do os reverse the deal, and there are no penalties. As a result, self-dealing is oportunistically and repetdly practiced. Turk Tuborg Bira \& Malt Sanayi A.S., the second largest brewery, purchased in 1998-9 overvalued sahres in Yasarbank, a sister company also controlled Tuborg's majority owner, Yasar Holding A.S. No wrongdoing was found in this instance; however, CMBT had already ordered the reversal of a series of improper share and real-estate transactions by Tuborg at the instigation of Yasar, in 1995-7.

Lithuania - enforcement of minority rights is via the courts

Courts are more actively used in minority rights enforcement than the Securities regulator. A commercial case takes 6 months at the local or district court ( $1^{\text {st }}$ instance) level, where 2-3 months are taken by parties mail communication and notices. If the case is appealed, there would be a delay of additional 6 months or even more at the Appellate and Cassation level.

Source: Romania and Lithuania ROSC's, "The Turkish Equity Marfket, Turkey ROSC" Zühtü Aytaç and Güven Sak, 2000. 
A potentially more efficient alternative of court action is arbitration. Colombia, where court redress is riddled by lack of specialization, costly litigation and lengthy court procedures, and a civil procedure takes an average of 26 months, ${ }^{75}$ a recent Bill revamps arbitration procedures. In order to use those for minority claims, companies need to have a special provision in the bylaws (currently few do). The parties can also subscribe a submission ad hoc in order to settle the dispute through an arbitration. The bill aims to simplify the procedure, give more responsibility to arbitration centers, and clarify the nature and scope of the functions performed by arbitration officers. Arbitration Tribunal judgments are binding and final, and there is very limited scope for appeal. Arbitration is rarely used, however, and usually by foreign or institutional investors. For example, in 1996 Banco de Colombia was acquired by Banco Industrial Colombiano and merged to create Bancolombia. Currently there is an arbitration between the former owner of Banco de Colombia, Jaime Gilinski and other shareholders, against the present owners of the bank in order to determine if there has been a fraud in the establishment of the shares exchange ratio. Chile has had an arbitration tradition for more than 50 years. It is currently creating a private arbitrageur practice. The regular court process is more open to the public, and therefore less discreet. Arbitration is faster, but more expensive than a court case. Courts also have more uncertainty in the outcome of the case. The final court judgment rarely includes a return in cash, and takes 2-3 years at least.

\subsection{Third Party Enforcement of minority protection}

\subsubsection{With a little help from one's friends: the role of creditors, institutional investors}

Bank monitoring may exert a positive influence on minority rights, to the extent that creditor and shareholder interests are aligned. In excessively cash-0rich firms, creditors may be too complacent to exert an effective monitoring effort. Bank monitoring depends on the health of banking system and the regulatory environment, as well as the availability of credit and other information. In South Africa, creditors are well-placed to play a larger role in corporate governance, although this has been extremely muted to date. Banks do not monitor company managers, because

${ }^{75}$ Source: Corporación Excelencia en la Justicia. 
corporate debt tends to be short-term, which means that banks tend to exercise discipline through 'exit' rather than 'voice'. There is generally an apparent apathy amongst institutional investors who do not participate in AGMs other than by granting their proxy in favor of the chairman of the meeting. Even with the corporate governance scandals that have plagued the South African market in recent times, institutional investors have not made their presence felt publicly leaving small minority shareholders to seek their own remedies. Institutional investors often hold up to $5 \%$ of a listed company's voting interest, and could constitute together as much as $30 \%$ of a company's voting interest, leaving about $20 \%$ or so within the free float for minority shareholders. The latter thus have very little leverage in challenging management abuse and underperformance. Institutional investors, representing retirement funds, unit trusts, life assurance plans, etc., tend to engage management directly in resolving their difficulties or issues, clearly an undesirable practice.

In theory, unlike small individual investors, there is greater incentive for large institutional investors to monitor management and try to influence its decisions rather than simply selling their stocks when they are dissatisfied. Although institutional investors count for $40 \%$ of the local market transactions in Hong Kong, they mainly trade on blue chip stocks and are not active in monitoring corporate management. ${ }^{76}$ An additional issue is that the fund market itself may be in early developing stages in most emerging economies. Indian institutional investors also usually do not undertake anti-management action, since they have cheaper ways to enforce their interests. Due to their position as both block-holders and lenders, they enjoy a certain clout, e.g. in the form of a veto on resolutions. In contrast, Chilean pension funds are active in control and supervision of controlling owners. They are required not to vote on directors nominated by the majority, and they require financial information from the firm on a regular basis.

\subsubsection{With a little help from one's friends: auditors}

Auditors are in possession of detailed company information, are usually in a good position to identify insider dealings. If good auditor standards and effective auditor and liability exist, and if further auditors are free from conflicts of interest, they may be a potent tool in minority value protection. The auditor independence stan-

\footnotetext{
${ }^{76}$ Ho, 2003, "Corporate Governance in Hong Kong: Key Problems and Prospects".
} 
dard in the Philippines requires "a state of mind, a manifestation of the professional integrity of the individual". Unfortunately, these conditions are not frequently fulfilled in developing countries. In Romania, good auditor standards are missing. Auditor opinions do not follow uniform rules, as a particular issuer non-compliance can produce an adverse, qualified, or unqualified opinion. CNVM has yet to set out its accreditation mechanism, and no auditor or audit firm has ever had its accreditation withdrawn as a consequence of an audit failure. While auditors are subject to civil, disciplinary, administrative, and criminal liabilities, there have been no court cases. In Peru, there are approximately 8,000 auditors chasing after a pool of 232 companies. This competitive market suggests that it is difficult for auditors to stand up to their clients. External auditors are known to sometimes provide support to management in the preparation of the financial statements. This puts them into a situation of conflict of interest, as they certify the veracity of something they prepared themselves. While in theory the Colegio de Contadores can disqualify a member for unethical behavior, in practice this does not happen. Finally, two examples of weak enforcement of auditor duties, by the SEC and the court, respectively. In Brazil, auditors can be sued for damages, but legal action and the appeal process take too long for it to be practical. In the bankruptcy of Banco Economico, for example, an Ernst and Young partner was suspended. However, he appealed and the final decision is yet not known. In India, qualified auditor opinions do not prompt automatic action from SEBI. Usually, if a company does not comply with proper audit practices or does not make available the necessary financial documents, the penalty ranges from a maximum fine of Rs 2,000 (USD 44) to imprisonment of up to six months. ${ }^{77}$ In practice, there have been no instances of imprisonment. Moreover, judicial delays diminish the deterrence-factor of such penalties.

\subsubsection{With a little help from one's friends: the role of the media}

Media and public opinion can play an important role in disciplining managers and controlling owners. ${ }^{78}$ In Korea much of the concerns on corporations' activities have been shared through the internet. ${ }^{79}$ Reputation and self-enforcement is important when general enforcement is weak. Shareholder activism and voluntary codes can raise awareness of the issues. In 2000, the Romanian Shareholders'

\footnotetext{
77 The forthcoming Securities Law Amendment Bill is expected to increase penalties substantially.

${ }^{78}$ Desai, Dyck, and Zingales, 2003.

${ }^{79}$ Berglof and Claessens, "Enforcement and Corporate Governance", 2003.
} 
Association advocated the amendment of law 52/1994 by Ordinance 229/2000. An intense debate centered around the (i) dilution of minority shareholders in capital increases; (ii) transfer of profits to subsidiaries; (iii) abusive transfer of assets or pledge of assets for loans to majority shareholders; (iv) year-long delays in dividend payments and; (v) limited access to information by outsiders and the near absence of minority representation on boards or censor commissions. The Ordinance was nevertheless ultimately declared null due to the efforts of the Foreign Investors Council. A number of groups have been active in sponsoring debate on corporate governance in Poland, including the Warsaw Stock Exchange which has held meetings for members of supervisory boards, the Center for Privatization, Business and Finance, which has sponsored a series of high level seminars on corporate governance, the Private Employers Federation whose chairperson, Henryka Bochniarz, is a member of the World Bank/OECD Private Sector Advisory Group on Corporate Governance and the Polish Association of Brokers \& Investment Advisers. The Polish press has played an active role in raising awareness, by reporting major cases concerning the operation of companies and by highlighting new local and international developments. Reputation concerns can prompt listed firms to unilaterally improve their corporate governance, in expectation to return to the market with new stock issues. For example, the Russian oil company Yukos was generously rewarded by the stock market when it unilaterally reformed its management and corporate governance. Studies show that the effect of unilateral improvements still falls short of regulatory enforcement. ${ }^{80}$ Similar efforts have been undertaken in several countries, where a "model corporate governance" tier of firms was forovernance tier of firms was forh example is the Novo Mercado in Brazil, where currently only two firms are listed.

\section{Section IV. Conclusion}

The world is characterized by concentrated ownership, and controlling shareholders often hold majority or supermajority of the voting power, which effectively empowers them to take any and al corporate decisions. Regulation, private enforcement, and third parties who are major corporate governance players can be potential mechanisms to address the corporate governance problems stemming from much unchecked corporate power. The examples and literature overviewed above suggest

\footnotetext{
${ }^{80}$ Black et al. (2002), Durnev and Kim (200X) and Klapper and Love (2003).
} 
self-dealing as the most damaging concern in low-income countries, and insider trading as a major shortcoming of capital markets in middle-income countries. Wellfocused disclosure provisions can make significant inroads into protecting corporate value from expropriation. Strict enforcement of a set of parsimonious, simple, transparent rules would conserve scarce state resources and ensure the effectiveness of corporate governance policies.

A set of such rules that is suggested by practice and policy experience includes, for lowincome countries, minimum dividend provisions, and oppressed minority mechanisms: dissenting shareholder rights, audit at company expense. Countries with poorly functioning court system may beed to rely inasted for enforcement issues on the securities regulator. For mid-income emerging markets, a set of potentially effective tools comprises pre-emptive rights, minority rights to elect a director, takeover provisions (equal prices, tag-along, freeze-outs), board independence and audit committees, Annual General Meeting (AGM) powers in defense of minorities, third parties (creditors, institutional investors, auditors, and the media). 